\title{
Coilgun - canhão eletromagnético
}

Jean Dorneles, Nicholas Prado, Gustavo Silva, Antonio Manoel

Universidade de Uberaba

jean_aleff@hotmail.com,nickprado@msn.com,ggustavo.lucas@gmail.com,antonio.manoel@uniube.br

\section{1 - Introdução}

A arma eletromagnética (ou canhão eletromagnético) começou a ser estudada como uma forma de melhorar o poderio militar. Atualmente, a marinha dos Estados Unidos vem fazendo testes e atingiu níveis extraordinários sendo capaz de lançar projéteis a mais de $300 \mathrm{~km}$ de distância e a uma velocidade próxima a Mach 9 (9 vezes a velocidade do som). Embora existam muitas interações de uma arma de bobina eletromagnética em livros, filmes, jogos, não houve qualquer introdução deste aparelho para consumo público.

Informações sobre este tipo de projeto existem apenas em pedaços fragmentados na literatura e na internet. A equipe foi incapaz de encontrar uma concentração de material que detalhasse 0 processo a partir de uma perspectiva de primeiros princípios. Propõe-se o processo de concepção de uma arma de bobina através de modelos físicos derivados, tentando compreender a física abordada.

O funcionamento é conceitualmente simples : um campo eletromagnético é formado ao passar corrente por uma bobina, o campo gera um força que atua sobre o projétil no interior da bobina acelerando-o ao longo do percurso.

Todas as aplicações para deste conceito envolveria algum tipo de projétil. O lançamento poderia ser de forma semelhante, mas diferenciáveis: mover um vagão de metrô, a criação de um sistema de elevador, arma de alta velocidade de lançamento, pistola de pregos, etc.

\section{2 - Materiais e métodos}

Ultilizaremos um equipamento já existente como base para a criação de nossa "Coilgun", modificações podem ser feitas durante a montagem e também, peças podem não serem encontradas nas dimensões citadas.

Equipamentos ultilizados:

-03 Bobinas enroladas com fio de cobre esmaltado medida 21AWG;

-01 Tubulação de policabornato;

-01 Folha de policabornato 1/8 " x 12" x 12";

-01 Arduino;

-03 Capcitores 3900uF 400V;

-03 Capacitores 100uF 450V;

-03 Fotosenssores;

-03 Transistor;

-03 diodos de rápida recuperação;

-03 Indutores 500uH;
-03 Foto Interruptor Breakout Board;

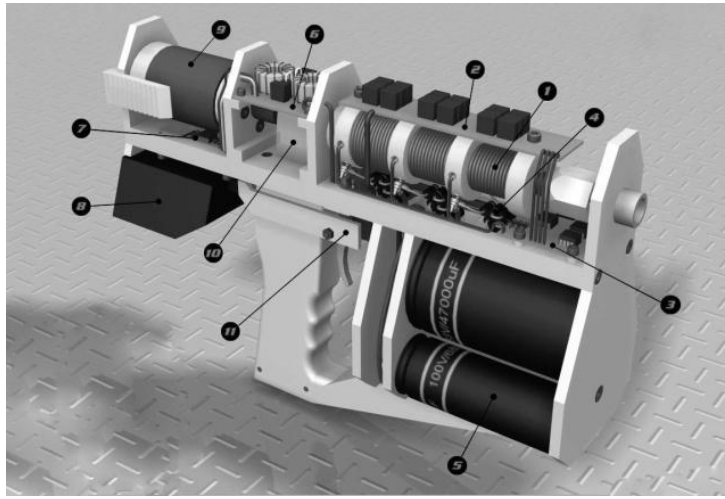

Figura 1 - Esquema 3D "Coilgun"

\section{3 - Resultados e discussão}

Teoricamente, se mais estágios forem adicionados, a potência da bobina da arma aumentará. No entanto, conforme mais estágios forem adicionados, os benefícios extras de diminuir o dispositivo torna-se impraticável, derrotando o propósito de ter uma pistola de pregos portátil.

Conseguimos apenas um tiro por vez que o capacitor é carregado, já que $90 \%$ da tensão é descarregada quando o projétil é disparado.

O peso do protótipo é de aproximadamente 15 quilos. Os capacitores, a bobina, e as baterias são as principais razões pelas quais o peso é tão alto. Uma maneira de obter um menor peso seria empregar o mecanismo que as pistolas de pregos pneumáticas usam, ou seja, utilizar uma mangueira conectada à arma e carregar os capacitores pesados e/ou baterias em um recipiente separado.

O protótipo final terá um interruptor principal que irá ligar / desligar todos os componentes em o circuito por precaução. Durante a experimentação, várias faíscas foram criadas devido às altas tensões envolvidos neste projeto. Este problema foi resolvido ao mover todos os componentes a uma placa de circuito, desde então, não ocorreu grandes catástrofes envolvendo faíscas ou arcos elétricos.

www.uniube.br/entec - UNIUBE Campus Aeroporto - Uberaba/MG 
8 EnTec - Encontro de Tecnologia da UNIUBE / 28 a 30 de outubro de 2014

\section{4 - Considerações finais}

A arma ainda não foi totalmente concluída mas no estágio em que estamos ja encontramos alguns problemas quem conseguimos resolver como o fato dela criar faiscas quando ligada devido a alta tensão.Esperamos conseguir desenvolver uma arma eletromagnética com a finalidade de lançar projéteis em um alvo a uma certa distância.

\section{5 - Referências}

"Construa um canhão eletromagnético".Acessado em 21/0/2014.Disponivel em $<w w w . n e w t o n c b r a g a . c o m . b r / i n d e x . p h p / p r o j e t o s$ -educacionais/5433-mec120>

"Canhão Eletromagnético". Acessado em 20/09/2014.Disponivel em $<$ www.tecnodefesa.com.br/materia.php?materia $=5$ 23/>

"Coilgun." Wikipedia. Wikimedia Foundation, 05 de Setembro de 2014 Web. <Http://en.wikipedia.org/wiki/Coilgun>.

\section{Agradecimentos}

À Univerisdade de Uberaba pelo empréstimo de equipamentos para testes. 